Ahmad, R., \& Scott, N. (2014). Managing the front office department: staffing issues in

Malaysian hotels. Anatolia: A multi-disciplinary Journal 25(1) 24-38.

\title{
Managing the front office department: Staffing issues in Malaysian hotels
}

This study examined hotel staffing issues with a focus on the front office department. While there are numerous studies reporting high employee turnover in the hospitality industry few have examined issues that contribute to this turnover or broader related staffing issues. To address this gap, this study conducted semi-structured interviews with fourteen front office managers from hotels with various levels of service in the northern region of Malaysia. Results identified a number of poorly studied issues that contribute to staff turnover. The findings indicate that hotel staff turnover and the consequences for hotel performance are due to a complex series of causal factors. Results may be used by hotel managers in addressing their staffing issues and improving performance.

Keywords: hotel turnover, causal factors, front office, human resource management, Malaysia

\section{Introduction}

The importance of human resource management for service quality, customer satisfaction and loyalty, competitive advantage and organizational performance is highlighted in many theories, models and empirical studies (Dimitrov, 2012; Hayes \& Ninemeier, 2008; Kusluvan, Kusluvan, Ilhan \& Buyruk, 2010; Solnet \& Kandampully, 2008). Human resource management policies and practices directly influence employee knowledge, skills, abilities, attitude and behaviour which are crucial for firm specific advantage (Ahmad, Solnet \& Scott, 2010; Kusluvan et al., 2010). Human resource practices such as training and career development seek to motivate, satisfy and retain employees (Hemdi, 2006; Whitener, 2001) and hence to result in satisfied and loyal customers (Koys, 2001; Kusluvan et al., 2010). Managing employees effectively is one of the biggest challenges faced by hotel managers (Kapoor \& Solomon, 2011; Singh, Hu \& Roehl, 2007).

The challenge of managing human resources has been widely discussed in the hospitality management literature (Kusluvan et al., 2010) especially focusing on 
employee turnover (Cheng \& Brown, 1998; Guthrie, 2001; Huselid, 1995; Koys, 2001; Kuria, Alice \& Wanderi, 2012; Pare \& Tremblay, 2007; Pizam \& Thornburg, 2000) and staff shortages (Baum \& Devine, 2005; Davidson, Guilding \& Timo, 2006; Singh, et al., 2007). In addition, a variety of other human related issues may be identified such as difficulty of attracting and retaining personnel, managing a diverse workforce, low prestige and status of hospitality jobs, aging population and disadvantage of older workers, the need to train employees in new communication and information technologies, HIV/AIDS issues, employment law, minimum wages and restrictive government policies (Kusluvan et al., 2010). This study seeks to examine the importance and influence of these issues on staff turnover and hotel management effectiveness in Malaysia.

While there is a body of literature pertaining to staffing issues in the hospitality industry in other countries (Alonso \& O’Neill, 2009; Davidson et al., 2006; Kuria et al., 2012; Kusluvan et al., 2010; Pizam \& Thornburg, 2000; Rok, 2012), studies in Malaysia are limited. Previous Malaysian studies have focused on turnover intention and are quantitative in nature (Chew \& Wong, 2008; Hemdi \& Nasurdin, 2006; Hemdi \& Nasurdin, 2008; Hemdi \& Rahim, 2011; Khalid, Jusoff, Ali, Ismail, Kassim \& Rahman, 2009; Radzi, Ramley, Salehuddin, Othman \& Jalis, 2009; Ryan, Ghazali \& Mohsin, 2011) and many hotel staffing issues have been ignored (Kusluvan et al., 2010). In particular few studies have focused on the Front Office Department (Patah, Zain, Abdullah \& Radzi, 2009). This study is the first to use an inductive and qualitative approach to examine staffing issues faced by front office managers in Malaysia and the solutions they are adopting. It focuses on front desk employees because irrespective of hotel types and sizes, this department is the main contact point for guests (Baum \& Devine, 2005) and provides guests' first impression of a hotel. The success of a hotel largely depends on front office staff service delivery (Slatten \& Mehmetoglu, 2011) and it is crucial to ensure that employees are competent in technical, communication, interpersonal and language skills (Baum \& Devine, 2005).

\section{Staffing Issues in the Hospitality Industry}

The importance of staffing issues in the hospitality industry is driven by the high dependence of hotel performance on its employees (Kusluvan et al., 2010). Empirical studies indicate a wide variety of approaches to the management of human resources (Ahmad et al., 2010; Lockyer \& Scholarios, 2004) influenced by the strategic response 
to the nature of the internal and external environment (Davidson et al., 2006; Wilton, 2006). Companies may adopt strategies of innovation, quality enhancement or cost reduction (Schuler \& Jackson, 1987). Innovation and quality enhancement are strategies requiring a long term perspective and involve improving the quality of products and services. A cost reduction strategy involves producing products and services at the lowest cost. While the long term perspective requires high investment in human resources, a cost reduction approach to hospitality services reduces investment in human resources and results in various problematic staffing issues (Ahmad et al., 2010; Davidson et al., 2006; Kusluvan et al., 2010).

The human resource literature suggests hotels seeking to lead their competitors and become known for their quality service should be selective in staffing, provide orientation and training, offer competitive and fair pay and benefits, and involve and empower employees (Guthrie, 2001; Kusluvan et al., 2010; Lepak et al., 2007; Pare \& Tremblay, 2007). These practices require high investment and may be thwarted by employee turnover and demand seasonality. A career in the hotel industry is often built by moving from one organisation to another and this practice is common in large and luxury hotels (Scott \& Revis, 2008). Furthermore, demand in the hospitality industry fluctuates and while having too few employees may impair service quality, having too many permanent (full-time) employees is a risk because labour cost is the largest operating expenditure (Knox \& Walsh, 2005; Nankervis, 2000). High employee turnover and fluctuating demand has led hotel managers to adopt a cost reduction strategy by practising ad hoc staffing, providing minimal and on the job training, no career advancement opportunities, limited employment security and inferior compensation (Alonso \& O’Neill, 2009; Wilton, 2006). This results in a number of staff related issues for hotel managers to deal with.

\section{Issues and Solutions}

A review of the hospitality literature indicates staffing issues can be grouped around issues of high employee turnover, difficulty in attracting and retaining skilled workers, staff shortages, and poor discipline and job commitment. Among these issues, employee turnover appears to be the most challenging (Alonso \& O’Neill, 2009). Employee turnover is defined as the voluntary or involuntary permanent withdrawal of a staff member from an organisation (Robbins et al., 2001, p.27). Employee turnover is a major problem in the hotel industry, especially in developed countries such as the 
United Kingdom and Australia (Cheng \& Brown, 1998; Wilton, 2006). Excessive turnover involving valuable staff members disrupts and hinders the effectiveness of an organisation (Robbins et al., 2001). Reducing turnover is important because it reduces recruitment, selection and training costs, and improves the quality of service delivered (Cheng \& Brown, 1998).

In Malaysia, a number of studies have focused on employee turnover intentions (Chew \& Wong, 2008; Hemdi \& Nasurdin, 2006; Hemdi \& Nasurdin, 2008; Hemdi \& Rahim, 2011; Khalid et al., 2009; Radzi et al., 2009; Ryan et al., 2011). Malaysian studies have found that respondents with high intention to leave are: those who want transient employment, were influenced by others to seek employment in the industry, and are more oriented towards peer group friendship rather than the specific work (Ryan et al., 2011). Human resource practices (Hemdi \& Nasurdin, 2006; Chew \& Wong, 2008), procedural and distributive justice (Hemdi \& Nasurdin, 2008; Radzi et al., 2009), organizational citizenship behaviour (Khalid et al., 2009) and a psychological contract (Hemdi\& Rahim, 2011) contribute to reduceing turnover intention. The negative relationship between helping behaviour and turnover intention is stronger among female employees (Khalid et al., 2009). Hemdi and Rahim (2011) found that job content (challenging, comprehensive and diverse works) is a significant predictor of hotel managers' turnover intention. They also found that age is a significant variable in explaining reasons for intention to leave the organisation. Promotion opportunities and salary are significant predictors of turnover intention for the 18-30 age group members who had just started their career while work-family balance was important for those in the 31-40 age group and the older age group (41-50) members are more likely to leave an organisation with a policy of performance related pay.

Other research in Malaysia has examined the attraction and retention of skilled and efficient employees (Chew \& Wong, 2008). A low level of human capital among the workforce has been found to be a cause for a shortage of skilled labour shortage in Malaysia (Wong \& Baum, 2006). Although the number of hotel schools is increasing, there is a declining interest among hospitality students and graduates in a career in the hotel industry (Zahari, Hanafiah, Othman, Jamaluddin \& Zulkifly, 2010). As the result, hotel organisations employ foreign workers or less skilled high school graduates who are willing to take an entry level position and work for low wages (Ahmad \& Zainol, 2011). Such a situation makes managing staff for superior service delivery a challenging task. 
Studies outside Malaysia have identified a number of other issues facing hotel managers including a lack of commitment, a lack of discipline and a poor work ethic among employees (Alonso \& O’Neill, 2009). The hotel industry is characterized by significant absenteeism (Chew \& Wong, 2008) and employees may leave a hotel without notice or the manager being aware (Alonso \& O’Neill, 2009). Absenteeism is predominantly caused by work related characteristics (Pizam \& Thornburg, 2000) and is a serious problem when it is extensive and prolonged (Cole, 2008). Lateness and absenteeism are symptoms of withdrawal behaviour. Lishchinsky and Zohar (2011) define withdrawal behaviour as a set of attitudes and behaviours used by employees when they decide to be less participative. Work pressures especially during peak periods are another reason for staff turnover (Alonso \& O’Neill, 2009).

A number of general guidelines for hospitality human resources managers are available to address these staffing issues (Kusluvan et al., 2010; Nankervis, 2000; Wilton, 2006) and represent "HR best practice” (Cho, Woods, Jang \& Erdem, 2006; Hoque, 2000; Sun et al., 2007). These include selective staffing (Cho et al., 2006; Kusluvan et al., 2010; Nankervis, 2000), training, fair pay, a humane management style and empowered staff. Selective staffing is crucial to enhance employee commitment and mitigate employee turnover as it exerts a strong influence on an organisation's culture (McGunnigle \& Jameson, 2000). Selective staffing refers to attracting enough applicants to ensure qualified candidates are among them (Millmore, 2003). A realistic job preview allows candidates to assess the organisation effectively and to decide whether they are suitable for the organisation (Millmore, 2003; Raub \& Streit, 2006). Selective staffing also involves use of multiple reliable selection methods and involving many stakeholders in selection decision-making (Millmore, 2003).

Orientation and training familiarises new employees with the organisation and increases employees' knowledge, skills and abilities to perform their required tasks (Cheng \& Brown, 1998; McGunnigle \& Jameson, 2000). Training should involve a training needs analysis, professionally designed training courses, competent trainers, as well as training evaluation and records keeping (Hayes \& Ninemeier, 2008). Offering competitive and fair pay to employees is also crucial for employee retention (Davidson et al., 2006; Kline \& Yu-Chin, 2007; Kusluvan et al., 2010; Nankervis, 2000). Hospitality industry non-managerial employees have low pay compared to other industries, leading to high employee turnover, staff shortages and difficulty in attracting and retaining skilled staff (Alonso \& O’Neill, 2009; Kuria et al., 2012; Sturman, 2001). 
To retain experienced and competent employees, hotels must provide attractive compensation with monetary and non-monetary rewards as well as recognition (Nankervis, 2000). Many hospitality firms however do not have sufficient funds to offer attractive and competitive compensation (Alonso \& O’Neill, 2009; Tudor, 2011). Practicing a friendly and humane supervision and management style can help satisfy and retain employees by reducing the stress of the working atmosphere (Alonso \& O’Neill, 2009) and creating commitment, trust and a motivating work environment. A manager with good communication skills and rapport with staff members recognises, respects and involves them in decision making (Ahmad et al., 2010; Kusluvan et al., 2010). Organizations that empower employees, consider job redesign, improve the condition of employee accommodation, create a culture conducive to organisational performance, assess organizational performance and provide a strong leadership and vision (Kusluvan et al., 2010).

This literature review has identified a number of issues or management practises that affect staff turnover in the hotel sector. In this research study, these practices are examined to determine their practicality and use as solutions to staffing issues in hotels of various level of service in Malaysian northern region.

\section{Methodology}

A qualitative research methodology and semi-structured interview method was used for this study. Data collection was carried out in November 2011 using convenience sampling. Hotel managers were recruited by phone. Fourteen front office managers from hotels of various levels of services were individually interviewed face-to-face. On average the interview on staffing issues took 40 minutes. Two main questions were asked: "What are the staffing issues faced by front office managers?" and "How do managers solve these issues?” The interviews were recorded, transcribed and analyzed using thematic content analysis (Krippendorff, 2004). Content analysis is a research technique for making replicable and valid inferences from texts and allows a researcher to discover what the text reveals. With thematic content analysis, data is analysed by themes that emerges from the data. Each transcript was systematically and thoroughly read through to identify the staffing issues with codes allocated to portions of the text. Codes concerning various staffing issues were grouped based on their similarities into a small number of manageable themes. 
The participants were managerial (11) or supervisory (3) employees of hotels in Malaysian northern region and covered a range of experience, locations, hotel types, and hotel departments. The designation of the eleven managerial employees comprised of Front Office Manager, Assistant Front Office Manager, Room Division Manager and Operation and Sales Manager. For confidentiality purposes, a code name was assigned to every manager. The code name reflects the manager's position, the hotel's star rating and the location of the hotel. Three of the 14 managers were from Penang four and fivestar, and luxury boutique hotels. Their experience in the hotel industry ranged between eight to twelve years. Four managers were from Perlis: managing a three-star and a budget hotel. Their experience in the hotel industry ranged between three to eight years. One manager was from a three-star hotel in Perak. He had 18 years work experience in the hotel industry. Another six participants were from Kedah three-star and budget hotels. Their experience in the hotel industry ranged between two to twenty years. The participant's profile is summarised in Table 1.

\section{INSERT TABLE 1 HERE}

\section{Results}

Eight themes were identified by grouping the 20 issues initially identified. The eight themes and related issues were: staff shortage, high employee turnover, poor performance (slow, inefficient, incompetent and mistakes made at work), low-skilled employees (inability to use the property management system, poor english proficiency and poor communication skill), unpleasant personality (rude, bad attitude and rowdiness), lack of commitment (lateness, absenteeism, emergency leave, medical leave and taking long lunch breaks), excessive socialization (employees who socialize too much amongst themselves so that it negatively affects their work) and sexual harassment. Each of these themes is discussed below.

\section{Staff Shortage}

Off all the staffing issues, staff shortage was mentioned the most. According to the front office managers, staff shortages at the front office are caused by the difficulty of getting and retaining employees due to the low pay and long working hours. A four-star hotel pays as little as RM700 (AUD230) per month for front desk staff. FOM4SPG stated: 
"The hotel is recruiting people but many do not take the job because of the low pay. In the hotel industry the salary is very low. The starting salary for a front desk staff is between RM750 to RM1000. In the second year, then, their salary will increase to RM1000 and above."

Staff shortages make it difficult to deliver excellent customer service. One respondent (FOM4SPG) stated:

"To give good service it is important to have enough staff. When you have enough staff, they have enough time to provide good service to the customer. When you don't have enough people, you tend to finish everything faster. You cannot provide excellent service when you're rushing."

Two methods of solving the problem of staff shortages were discussed. One manager (RDM3SKH) resorts to employing part-timers from a nearby university while another (FOM4SPG) solves staff shortage problem by paying overtime. FOM4SPG (a manager) stated that paying overtime is his preferred solution because casual or part-time employment increases the rate of employee turnover and means employees do not have work experience. Furthermore, part-timers are not as competent as the permanent staff while paying overtime gives the opportunity for the staff to earn more.

\section{High Employee Turnover}

High employee turnover was mentioned as an issue by FOM4SPG and FOS3SK. According to FOS3SK: "A number of employees resigned because they were offered better salary by other hotels. They worked for two to three months, and then left." To address this problem, the manager conducted an exit interview to find out why they resigned and to try to persuade good employees not to leave.

\section{Poor Performance}

Poor performance was mentioned as an issue by eight participants. Incidents that reflect poor performance were giving guests the wrong key, cash shortages, and slow service. FOS3SPS stated: “There are staff that are not efficient but very few. Sometimes these employees give the wrong key to the guest. I guess they lose focus”. FOM3SPS also reported cash shortage problem. According to AFOMLBPG, some new staff members are slow and inefficient although they usually improved after training. 
Managers solved the issue of poor performance by providing continuous training. AFOM3SPS stated: "We have to send them for training. Retrain them so that they could deliver better service to the guests." According to OSMBPS, employees who have passed a probation period are given a warning letter if their work standard is below an acceptable level. After the third warning letter, the employee can be terminated. Solutions to problems of cash shortages varied from one organization to another. FOM3SPS stated: "In this hotel employees are required to cover the shortage by paying in cash or by salary reduction. Some hotels require employee to give a 'show cause' letter."

\section{Low-skilled Employees}

Low-skilled employees had poor communication skills, English proficiency, and problem solving and computer skills. Poor communication skills was mentioned by three participants and concerned phone conversations, poor English language proficiency and misunderstanding customers. According to AFOM5SPG, some employees misunderstood their duties and failed to follow instructions. FOS3SKH2 mentioned an inability to communicate in English was a problem with some staff. AFOM3SPS mentioned an inability to follow standard operation procedures in answering the phone:

"Some staff don't know how to answer the phone properly. In hotels we have a standard way to answer the phone. It's not like at home where we just say 'hello'. We have senior staff members who have worked here for a long time. It is very difficult to change their method of answering the phone but we are still trying” (AFOM3SPS).

According to AFOM3SPS problem solving skills are very important at the front office and a good problem solver is more easily promoted. However, most employees were unable to solve guest problems and he is still seeking the best technique to improve them. He stated:

"Problems will just come through that door. People will just appear with problems and I'm afraid if there are situations that they don't know how to handle... I will keep trying to train them until they can solve the problems themselves". 
Another skill required but reported lacking by AFOMLBPG and FOS3SKH2 was the ability to use the computer property management system. Most hotels in this study, except for budget hotels with less than forty rooms use a property management system. This makes it necessary for employees to be computer literate. All participants in this study solved issues of low-skill with training although training senior non-managerial staff appears to be more challenging.

\section{Unpleasant Personality}

An unpleasant personality was reported as an issue by six participants and was related to rudeness, unfriendliness and “bad attitude”. AFOM3SPS reported having these types of problems with new young employees.

"They are very rowdy, and they expect people to accept them the way they are, especially when they live in the area (neighbourhood) where people are used to it. We have to slow down the rowdiness and improve their communication skill. To them it is just being cool... because they are young. But at the Front Office we can't do that. We have to be professional” (AFOM3SPS).

Besides training, the unpleasant personality issue was solved by trying to hire suitable employees and by counselling. AFOM5SPG stated: "One of the front office staff refused to let a guest borrow a hand phone charger and was rude to the guest. So we had to train this staff, give her counselling and explain to her why her actions led to guests complaints.”

\section{Lack of Commitment}

Lack of commitment was the most frequently mentioned staffing issue. Absenteeism, lateness, long lunch break, medical leave and emergency leave were some of the staffing issues that were related to a lack of commitment. Absenteeism and lateness were most frequently mentioned. RDM3SKH was the only manager who mentioned long lunch breaks and perceived it as a minor issue that could be solved by verbally advising the staff. According to FOS3SKH, frequent absenteeism is a serious problem to the front desk department because there are just a few of them to run the operation (staff shortages). The problem is worst if it happens on a busy day when the hotel occupancy is high. AFOM3SPS stated: “Just because one staff was absent on a busy 
day it took us a very long time to register the guests. That day we received many complaints because they had to wait for so long”.

The participants discussed actions to solve the lack of commitment issue. Lateness was handled by taking disciplinary action. According to FOM3SPS, employees who were late were given three verbal warnings. When the problem continues, they were required to give a "show cause" letter. Show cause letter is a letter written by an employee after a show cause notice is issued by the manager. It provides employees the opportunity to justify or explain the cause of their conduct that violates the policy and appointment terms and conditions. The letter is filed and documented. This affected their performance appraisal and year end salary increment. If there was no improvement they are given a warning letter. According to AFOMLBPG, employees who received three warning letters were immediately terminated. AFOM5SPG stated: “Usually, when staff are asked to give a show cause letter, he will take note of his mistakes. He realises that he is being monitored and he will be more careful of his actions". AFOM3SPS sort to avoid this issue by checking an applicant's medical background prior to employment to avoid frequent medical leave.

\section{Excessive Socialization}

Excessive socialization was reported as a problem by three participants. According to FOMB1KH, her front desk employees were always chatting and gossiping with each other instead of doing their work. FOS3SPS stated that her employees preferred to share their dissatisfaction towards management with their colleagues instead of using the proper channel for a complaint. She explained that sometimes a manager may unintentionally show favouritism towards a member of staff and this causes dissatisfaction among other staff who gossip about the matter. AFOM3SPS mentioned that in his hotel, employees mistakenly thought that no action was taken about an employee who was late and they were unhappy about it. However, action was taken but due to the confidentiality of the matter others were not informed. AFOM3SPS stated: "Staff talk without even confirming [the problem]. The grapevine [informal transmission of confidential information] has created an inharmonious working atmosphere”. AFOM3SPS tried to address this issue by having daily briefings and weekly meetings. In these meeting, staff members were given the authority to speak and there was "two- 
way communication”. This was a way to avoid 'the grapevine' and excessive socialisation.

\section{Sexual Harassment}

The issue of sexual harassment was mentioned by only one participant. According to FOS3SKH, sexual harassment rarely happens but it is a serious problem when it occurs especially for female employees. FOS3SKH stated: “For sexual harassment, the front office manager will take a quick action. She will investigate if the report is true or it is just a joke. If the report is true, the manager will punish the harasser by taking disciplinary action and reassess his performance on the job."

The staffing issues faced by front office managers in this study is summarised in Table 2.

\section{INSERT TABLE 2 HERE}

\section{Discussion}

Among the issues mentioned, staff shortages, poor performance and lack of commitment were the staffing issues considered as most important by managers and will be discussed below. Less frequently mentioned issues were: low-skilled employees, unpleasant personality, excessive socialisation, high employee turnover and sexual harassment.

The issue of staff shortages in the hotel industry has been discussed and documented in the literature (Kusluvan et al., 2010). Staff shortages are especially important when the hotel is running at a high occupancy. Usually hotels do not employ the number of staff required to cater for occupancy because room occupancy fluctuates and seldom reaches its maximum (Malaysian Association of Hotels, 2012). In this study, concern for service quality has led a four-star hotel manager in Penang State to choose to pay her experienced and efficient employee overtime instead of taking on part-timers. Penang is the State with the most competition for employees and the highest cost of living. The implication is that in this vicinity, managers may need to pay overtime as otherwise they may not be able to obtain suitable employees.

Poor performance was also frequently mentioned by hotel managers from various levels of service and locations in this study. The managers' solution to poor performance was training and retraining. Although high employee turnover means training effort may be a waste of time and money, it is necessary to provide training 
because it can also lead to employees and customer retention (Omar, 2010). In this study, employees who have completed their probation period were terminated if they failed to improve their performance after going through various extensive training programmes. The identification of the cause of poor performance is necessary for corrective action. This is best done through a close observation of employees' performance and a two way discussion with them (Ahmad et al., 2010). Failure of training programs to improve employee performance is either because the employee is not fit to work in the industry or by training programs that are not effective. Therefore, hotel managers need to assess the effectiveness of training (Hayes \& Ninemeier, 2008), and to provide a cost-benefit analysis of the training programme in order to obtain approval from owners who are reluctant to spend on training (Alonso \& O’Neill, 2009). This study has discussed action taken due to discovery of cash shortage varies among hotels. Hotels usually require cash replacement and "show cause letter" in this case.

Another issue that was frequently mentioned by the managers in this study was lack of staff commitment. Poor performance due to lack of training or resources is perceived as less serious compared to when it is caused by laziness or a poor attitude to work (Cole, 2008). While providing training and resources is a manager's responsibility, commitment to work is an employees' obligation to the employer (Shah, Farooq, Munir, Mahmood \& Saeed, 2011). This may explain why, regardless of the types of industry, prolonged absenteeism and poor performance are among the most common reason for disciplinary actions (Cole, 2008). Consistent with Cole (2008), this study discovered that the issue of poor performance and lack of commitment is addressed by taking disciplinary actions.

An interesting finding of this study is the problem of unpleasant personality. This may reflect workforce generational differences as the manager reported having problems with new staff members who are younger and appear to reflect Generation Y characteristics (those born between 1979 and 1994) (Solnet, Kralj \& Kandampully, 2012). This generation is considered as more confident, expressive, and are sometimes perceived to have poor communication and problem-solving skills (Kapoor \& Solomon, 2011). The managers in this study addressed the issue by practising selective staffing, training and counselling so these employees could find out about the consequences of their actions, consistent with the suggestions in the literature concerning Generation $\mathrm{Y}$ (Kapoor \& Solomon, 2011; Solnet et al., 2012). A thorough explanation of the task is necessary because members of Generation $\mathrm{Y}$ are reluctant to perform simple tasks that 
lack depth or meaning for them (Kapoor \& Solomon, 2011). The increasing number of Generation Y in today's workforce requires employee management that is tailored to satisfy their needs (Solnet et al., 2012). Front Office Department staff require communication, problem solving and computer skills. Poor communication results in misunderstandings and poor problem solving skill, and an inability to use the property management system lead to service delays. Managers in this study address these issues with training as these generic skills are important for service delivery efficiency (Baum \& Devine, 2005).

Excessive socialization at work may create conflicts with colleagues and management, reduce employees' productivity and annoy guests (Tudor, 2011). According to Tudor (2011), socializing on the job helps employees form positive connections with their colleagues and creates work enjoyment which is beneficial for employee and customer retention. Socialization with guests is one of the strategies used by leading hotels such as Club Med to retain its customers (Solnet \& Kandampully, 2008). Socialization or open communication between management and employees leads to employee's job satisfaction, organisational commitment and retention (Ahmad et al., 2010; Hoque, 2000). However, when socialisation among employees is excessive, it is perceived as social loafing and is detrimental for organisational effectiveness. This issue was addressed by the managers in this study through two-way communication during daily briefing and weekly meeting.

Despite the importance of employee turnover issue in the hotel management literature, this issue was mentioned by only two managers. This is consistent with Nankervis (2000) who stated that employee turnover is not as serious in Malaysia, where hotels are often successful in recruiting employees who aim to stay with the same firm for a long time. Managers addressed this issue by conducting exit interviews and trying to persuade the good employees to stay. A friendly working environment to nurture and provide self-fulfilment to employees is also effective in reducing employee turnover (Alonso \& O’Neill, 2009). Sexual harassment was mentioned by only one manager who stated that it rarely happens. Reports of sexual harassment were investigated and addressed with disciplinary action. Human resource managers have the authority to conduct harassment investigations and administer discipline (Tyner \& Clinton, 2010). In the United States some employers ban workplace romance to avoid sexual harassment claims arising from such relationships (Boyd, 2010). However, Boyd (2010) argued that such policy is an intrusion of employees' rights. Furthermore, there 
are other sexual harassment policies that are effective for sexual harassment prevention such as continuous training on sexual harassment for the managers (Tyner \& Clinton, 2010) and employees (Eaton, 2004).

\section{Implication}

This study contributes to the hotel management literature by providing empirical evidence of staffing issues in the Malaysian hotel industry. While some of the issues identified have been previously studied within the Malaysian context, others such as absenteeism and lateness have not received attention (Khalid et al., 2009). This study has also identified issues of excessive socialization, poor performance, low-skilled employees, staff shortage, high employee turnover, unpleasant personality and sexual harassment.

This study contributes to better performance of the industry by providing suggestions to solve the staffing issues identified. Although the context of study is Malaysia, the results may benefit managers in other countries with similar staffing issues (Alonso \& O’Neill, 2009; Pizam \& Thornburg, 2000). Substantial evidence supports the effectiveness of human resource management in improving staffing issues such as those identified in this study (Connolly \& McGing, 2007; Lepak et al., 2007; Pare \& Tremblay, 2007; Sun et al., 2007). The importance of human resource techniques such as training (repeatedly discussed in this study), selective staffing, career development opportunity, employment security, competitive compensation, empowerment and effective communication have been identified. However, this is an exploratory qualitative study and further research is needed to allow generalization of its findings or of particular aspects such as withdrawal behaviour (Khalid et al., 2009).

\section{Conclusion}

There has been a rapid growth of tourism industry in Malaysia since 1970 (Goldsmith \& Zahari, 1994). To enhance Malaysian tourism industry positive image, the facilities and services provided by tourism related operators should meet customers' expectations. However, meeting customers' expectation is always a challenge especially in the hotel industry due to the industry's labour intensiveness. This investigation of staffing issues in hotels of various sizes and location using qualitative study has led to the discovery of various challenges in the Malaysian hotel industry and means to address them. It has 
highlighted issues that are rarely mentioned in the literature and has suggested solutions to current staffing issues faced by hotel managers.

\section{References}

Ahmad, R., Solnet, D., \& Scott, N. (2010). Human resource practices system differentiation: A hotel industry study. Journal of Hospitality and Tourism Management, 17, 72-82.

Ahmad, R., \& Zainol, N.A. (2011). What it takes to be a manager: The case of Malaysian five star resort hotels. $2^{\text {nd }}$ International Conference on Business and Economic Research Proceedings, 2040-2051.

Alonso, A.D., \& O’Neill, M.A. (2009). Staffing issues among small hospitality businesses: A college town case. International Journal of Hospitality Management, 28, 573-578.

Baum, T., \& Devine, F. (2005). Skills and training in the hotel sector: The case of front office employment in Northern Ireland. Tourism and Hospitality Research, 7 (3/4), 269-280.

Boyd, C. (2010). The debate over the prohibition of romance in the workplace. Journal of Business Ethics, 97, 325-338.

Cheng, A., \& Brown, A. (1998). HRM strategies and labour turnover in the hotel industry: A comparative study of Australia and Singapore. The International Journal of Human Resource Management, 9(1), 136-154.

Chew, Y.T., \& Wong, S.K. (2008). Effects of career mentoring experience and perceived organizational support on employee commitment and intentions to leave: A study among hotel workers in Malaysia. International Journal of Management, 25(4), 692-702.

Cho, S., Woods, R. H., Jang, S., \& Erdem, M. (2006). Measuring the impact of human resource management practices on hospitality firms’ performances. Hospitality Management, 25, 262-277.

Cole, N.D. (2008). The effects of differences in explanations, employee attributions, type of infraction, and discipline severity on perceived fairness of employee discipline. Canadian Journal of Administrative Sciences,25, 107-120.

Connolly, P., \& McGing, G. (2007). High performance work practices and competitive advantage in the Irish hospitality sector. International Journal of Contemporary Hospitality Management, 19(3), 201-210. 
Davidson, M., Guilding, C., \& Timo, N. (2006). Employment, flexibility and labour market practices of domestic and MNC chain luxury hotels in Australia: Where has accountability gone? Hospitality Management, 25, 193-210.

Davis, T.J., \& Gabris, G.T. (2008). Strategic compensation: Utilizing efficiency wages in the public sector to achieve desirable organizational outcomes. Review of Public Personnel Administration, 28(4), 327-348.

Dimitrov, D. (2012). Sources of meaningfulness in the workplace: A study in the US hospitality sector. European Journal of Training and Development, 36 (2/3), 351-371.

Eaton, D.E. (2004). Beyond room service: Legal consequences of sexual harassment of staff by hotel guests. Cornell Hotel and Restaurant Administration Quarterly, 45(4), 347-361.

Goldsmith, A., \& Zahari, M.S. (1994). Hospitality education in Malaysia: Filling the skill gap. International Journal of Contemporary Hospitality Management, 6(6), 27-31. Guthrie, J. P. (2001). High-involvement work practices, turnover, and productivity: Evidence from New Zealand. Academy of Management Journal, 44(1), 180-190.

Hayes, D.K., \& Ninemeier, J.D. (2008). Human Resources Management in the Hospitality Industry, New Jersey: John Wiley \& Sons, Inc.

Hemdi, M.A., \& Nasurdin, A. M. (2006). Predicting turnover intentions of hotel employees: The influence of employee development, human resource management practices and trust in organisation. GadjahMada International Journal of Business, 8(1), 21-42.

Hemdi, M. A., \& Nasurdin, A. M. (2008). Investigating the influence of organizational justice on hotel employees' organizational citizenship behaviour intentions and turnover intentions. Journal of Human Resources in Hospitality and Tourism, 7(1), 1-23.

Hemdi, M.A., \& Rahim, A.R. (2011). The effect of psychological contract and affective commitment on turnover intentions of hotel managers. International Journal of Business and Social Science, 2(23), 76-88.

Hoque, K. (2000). Human resource management in the hotel industry: Strategy, innovation and performance. London: Routledge. 
Huselid, M.A. (1995). The impact of human resource management practices on turnover, productivity, and corporate financial performance. Academy of Management Journal, 38(3), 635-672.

Kapoor, C., \& Solomon, N. (2011). Understanding and managing generational differences in the workplace. Worldwide Hospitality and Tourism Themes, 3(4), 308-318.

Khalid, S.A., Jusoff, K., Ali, H., Ismail, M., Kassim, K.M., \& Rahman, N.A. (2009). Gender as a moderator of the relationship between OCB and turnover intention. Asian Social Science, 5(6), 108-117.

Kline, S., \& Yu-Chin, H. (2007). Wage differentials in the lodging industry: A case study. Journal of Human Resources in Hospitality and Tourism 6(1), 69-84.

Knox, A., \& Walsh, J. (2005). Organisational flexibility and HRM in the hotel industry: evidence from Australia. Human Resource Management Journal, 15(1), 57-75.

Koys, D. J. (2001). The effects of employee satisfaction, organisational citizenship behaviour, and turnover on organisational effectiveness: A unit level, longitudinal study. Personnel Psychology, 54(1), 101-114.

Krippendorff, K. (2004). Content analysis: an introduction to its methodology (2nd ed.). Thousand Oaks: Sage.

Kuria, S., Alice, O., \& Wanderi, P.M. (2012).Assessment of causes of labour turnover in three and five star-rated hotels in Kenya. International Journal of Business and Social Science, 3(15), 311-317.

Kusluvan, S., Kusluvan, Z., Ilhan, I., \& Buyruk, L. (2010). The human dimension: A review of human resources management issues in the tourism and hospitality industry. Cornell Hospitality Quarterly, 51(2), 171-213.

Lepak, D. P., Taylor, M. S., Tekleab, A., Marrone, J. A., \& Cohen, D. J. (2007). An examination of the use of high investment human resource systems for core and support employees. Human Resource Management, 46(2), 223-246.

Lishchinsky, O.P., \& Zohar, S.E. (2011). Withdrawal Behaviours Syndrome: An ethical perspective. Journal of Business Ethics, 103, 429-451.

Lockyer, C., \& Scholarios, D. (2004). Selecting hotel staff: Why best practice does not always work. International Journal of Contemporary Hospitality Management, 16(2), 125-135.

Malaysian Association of Hotels. (2012). Surveys. Retrieved from http://www.hotels.org.my/home.asp?hdnMRef=58 
McGunnigle, P. J., \& Jameson, S. M. (2000). HRM in UK hotels: A focus on commitment. Employee Relations, 22(4), 403-422.

Millmore, M. (2003). Just how extensive is the practice of strategic recruitment and selection. Irish Journal of Management, 24(1), 87-108.

Nankervis, A. (2000). Human resource management strategies as competitive advantage: A case example of the hospitality sector in southeast Asia \& the pacific rim. Research and Practice in Human Resource Management, 8(1), 111133.

Omar, C.M. (2010). Relations of internal and external Malaysian hotel clients' satisfaction. Journal of Global Business Management, 6(2), 1-8.

Pare, G., \& Tremblay, M. (2007). The Influence of high-involvement human resources practices, procedural justice, organisational commitment and citizenship behaviours on information technology professionals' turnover intentions. Group \& Organisation Management, 32(3), 326-357.

Patah, M.O., Zain, R.A., Abdullah, D., \& Radzi, S.M. (2009). An empirical investigation into the influences of psychological empowerment and overall job satisfaction on employee loyalty: The case of Malaysian front office receptionists. Journal of Tourism, Hospitality and Culinary Arts, 43-62.

Pizam, A., \& Thornburg, S.W. (2000). Absenteeism and voluntary turnover in Central Florida hotels: A pilot study. International Journal of Hospitality Management, 19(2), 211-217.

Radzi, S.M., Ramley, S.Z.A., Salehuddin, M., Othman, Z., \& Jalis, M.H. (2009). An empirical assessment of hotel departmental managers turnover intentions: The impact of organizational justice. International Journal of Business and Management, 4(9), 173-183.

Raub, S., \& Streit, E. M. (2006). Realistic recruitment: An empirical study of the cruise industry. International Journal of Contemporary Hospitality Management, 18(4), 278-289.

Robbins, S. P., Millett, B., Cacioppe, R., \& Marsh, T. W. (2001). Organisational behaviour: Leading and managing in Australia and New Zealand (3rd ed.). Frenchs Forest, NSW: Pearson Education.

Rok, M. (2012). Labour market skill deficiencies in the tourism and hospitality industry. NaseGospodarstvo, 58(3/4), 80-87. 
Ryan, C., Ghazali, H., \&Mohsin, A. (2011). Determinants of intention to leave a nonmanagerial job in the fast food industry of west Malaysia. International Journal of Contemporary Hospitality Management, 23(3), 344-360.

Schuler, R. S., \& Jackson, S. E. (1987). Linking competitive strategies with human resource management practices. The Academy of Management Executive, 1(3), 207-219.

Scott, B. \& Revis, S. (2008). Talent management in hospitality: Graduate career success and strategies. International Journal of Contemporary Hospitality Management, 20(7), 781-791.

Shah, S.M., Farooq, M., Munir, S., Mahmood, Z., \& Saeed, G. (2011). Workforce ethics in organization procedure and practices. Interdisciplinary Journal of Contemporary Research in Business, 3(3), 1383-1398.

Singh, N., Hu, C., \& Roehl, W.S. (2007). Text mining a decade of progress in hospitality human resource management research: Identifying emerging thematic development. Hospitality Management, 26, 131-147.

Slatten, T., \& Mehmetoglu, M. (2011). Antecedents and effect of engaged frontline employees: A study from the hospitality industry. Managing Service Quality, 21(1), 88-107.

Solnet, D., \& Kandampully, J. (2008). How some service firms have become part of 'service excellence' folklore: An exploratory study. Managing Service Quality, 18(2), 179-193.

Solnet, D., Kralj, A., \& Kandampully, J. (2012). Generation Y employees: An examination of work attitude differences. The Journal of Applied Management and Entrepreneurship, 17(3), 36-54.

Sturman, M.C. (2001). Does the hospitality industry shortchange its employees and itself? Cornell Hospitality Quarterly, 42(4), 70-76.

Sutton, J., Verginis, C., \& Eltvik, L. (2003). Empowerment and customer satisfaction strategies in multi-cultural hotel restaurant environments: The Dubai case. Journal of Foodservice Business Research, 6(3), 77-104.

Sun, L. Y., Aryee, S., \& Law, K. S. (2007). High performance human resource practices, citizenship behaviour, and organisational performance: A relational perspective. Academy of Management Journal, 50(3), 558-577. 
Tudor, T.R. (2011). Motivating employees with limited pay incentives using equity theory and the fast food industry as a model. International Journal of Business and Social Science, 2(23), 95-101.

Whitener, E. M. (2001). Do "high commitment" human resource practices affect employee commitment? A cross-level analysis using hierarchical linear modelling. Journal of Management, 27, 515-535.

Wilton, N. (2006). Strategic choice and organisational context in HRM in the UK hotel sector. The Service Industries Journal, 26(8), 903-919.

Wong, K.Y., \& Baum, T.G. (2006) Tourism industrial development and multinational corporations: A case of productivity spillovers in Malaysia. In: Lazzeretti, L., \& Petrillo, C.S. Tourism local systems and networking. Oxford: Elsevier.

Yamashita, M., \& Uenoyama, T. (2006). Boundaryless career and adaptive HR practices in Japan’s hotel industry. Career Development International, 11(3), 230-242.

Yin, R. K. (2009). Case study research: Design and methods (4th ed.). Thousand Oaks: Sage.

Zahari, M.S., Hanafiah, M.H., Othman, Z., Jamaluddin, M.R., \& Zulkifly, M.I. (2010). Declining interest of hospitality students toward careers in hotel industry: Who's to be blamed? Interdisciplinary Journal of Contemporary Research in Business, 2(7), 269-287. 